\title{
Synthesis and characterization of bimetallic nanocatalysts and their application in selective hydrogenation of citral to unsaturated alcohols
}

\author{
S A ANANTHAN, R SURESH, K GIRIBABU and V NARAYANAN* \\ School of Chemical Sciences, Department of Inorganic Chemistry, University of Madras, \\ Guindy Campus, Chennai 600 025, India \\ e-mail:vnnara@yahoo.co.in
}

MS received 22 March 2013; revised 8 August 2013; accepted 24 August 2013

\begin{abstract}
TiO}_{2}$-supported bimetallic nanocatalysts were prepared and reduced at two different temperatures, $375^{\circ} \mathrm{C}$ and $575^{\circ} \mathrm{C}$ for selective hydrogenation of citral to corresponding unsaturated alcohols (geraniol (GOL) and nerol (NOL)). The nanocatalysts were characterized by difference techniques of Fourier transform infrared spectroscopy (FT-IR), Brunauer, Emmett and Teller (BET) surface area measurement, scanning electron microscopy (SEM), Energy Dispersive X-ray Analysis (EDAX), transmission electron microscopy (TEM), X-ray diffraction (XRD) and X-ray photoelectron spectroscopy (XPS). The prepared nanocatalysts are uniformly dispersed with an average particle size of 50-100 $\mathrm{nm}$ and zero valence metallic state. Catalysts reduced at higher temperature lead to an increase in selectivity toward unsaturated alcohols (GOL and NOL). The $\mathrm{Pt}-\mathrm{Ru} / \mathrm{TiO}_{2}$ shows higher activity compared to $\mathrm{Pt}-\mathrm{Pd} / \mathrm{TiO}_{2}$ and $\mathrm{Pt}-\mathrm{Au} / \mathrm{TiO}_{2}$ nanocatalysts. In addition, a second metal $(\mathrm{Ru})$ also leads to an increase in GOL and NOL selectivity during citral hydrogenation. Partially generated oxidized second metal species due to the difference in electronegativity, strongly binds the $\mathrm{C}=\mathrm{O}$ group and also paves the way for selective activation of $\mathrm{C}=\mathrm{O}$ bond.
\end{abstract}

Keywords. Bimetallic nanocatalysts; $\mathrm{TiO}_{2}$-supported; Pt-Ru; citral hydrogenation; unsaturated alcohols.

\section{Introduction}

Citral (3,7-dimethyl-2,6-octadienal) is an important monoterpenoid aldehyde with pairs of conjugated $\mathrm{C}=\mathrm{O}$ and $\mathrm{C}=\mathrm{C}$ bonds in addition to an isolated $\mathrm{C}=\mathrm{C}$ bond. Compared with other $\alpha, \beta$-unsaturated aldehydes, citral has an exclusive structure that renders hydrogenation reactions complex (as shown in scheme 1). Liquid phase selective hydrogenation of $\alpha, \beta$-unsaturated aldehydes to their corresponding alcohols is a process of major importance for the chemical industries, especially in the fine chemical industries, ${ }^{1-3}$ such as for the production of pharmaceuticals, detergents, cosmetics, flavours and fragrances. ${ }^{4,5}$ The reaction can lead to a variety of products, the $\mathrm{C}=\mathrm{C}$ double bond is hydrogenated to give a saturated aldehyde or the $\mathrm{C}=\mathrm{O}$ double bond is involved, yielding an unsaturated alcohol and hydrogenation of both can occur resulting in a saturated alcohol and also formation of cyclic products. Due to the fact that the $\mathrm{C}=\mathrm{C}$ bond presents a lower binding energy than the $\mathrm{C}=\mathrm{O}$ bond, the formation of saturated aldehydes is thermodynamically favoured, decreasing the selectivity to the unsaturated alcohol. ${ }^{6-12}$

\footnotetext{
*For correspondence
}

In the present study, selective hydrogenation of citral was studied, as this molecule and its unsaturated alcohols are of considerable interest in the perfumery industry. ${ }^{13,14}$

Hydrogenation reactions are generally catalysed by transition metals of group VIII of the periodic table. However, the selectivity of these metals with relation to hydrogenation of $\mathrm{C}=\mathrm{O}$ bond is specific for each metal in the order $\mathrm{Ir}>\mathrm{Pt}>\mathrm{Ru}>\mathrm{Rh} .{ }^{4}$ Extensive literature survey is available on the selective hydrogenation of $\alpha, \beta$-unsaturated aldehydes catalysed by different noble metals supported catalysts. ${ }^{15-17}$ In addition, catalytic hydrogenation of $\alpha, \beta$-unsaturated aldehydes is mostly based on supported-metal platinum-based bimetallic catalysts. ${ }^{18-30}$ Selectivity towards unsaturated alcohols (geraniol (GOL) and nerol (NOL)) could also be increased by metal deposition on supports such as $\mathrm{SiO}_{2}, \mathrm{TiO}_{2}$, etc. Hydrogenation of the $\mathrm{C}=\mathrm{O}$ bond can be promoted by the presence of second metals. Noble metal supported by metal oxides during catalytic activity and selectivity of hydrogenation reaction with reduction at high temperature has attracted much attention compared to reduction at lower temperature.

In this study, we report the preparation of $\mathrm{TiO}_{2}$ supported bimetallic nanocatalyst, by impregnation method, being reduced at two different temperatures, 


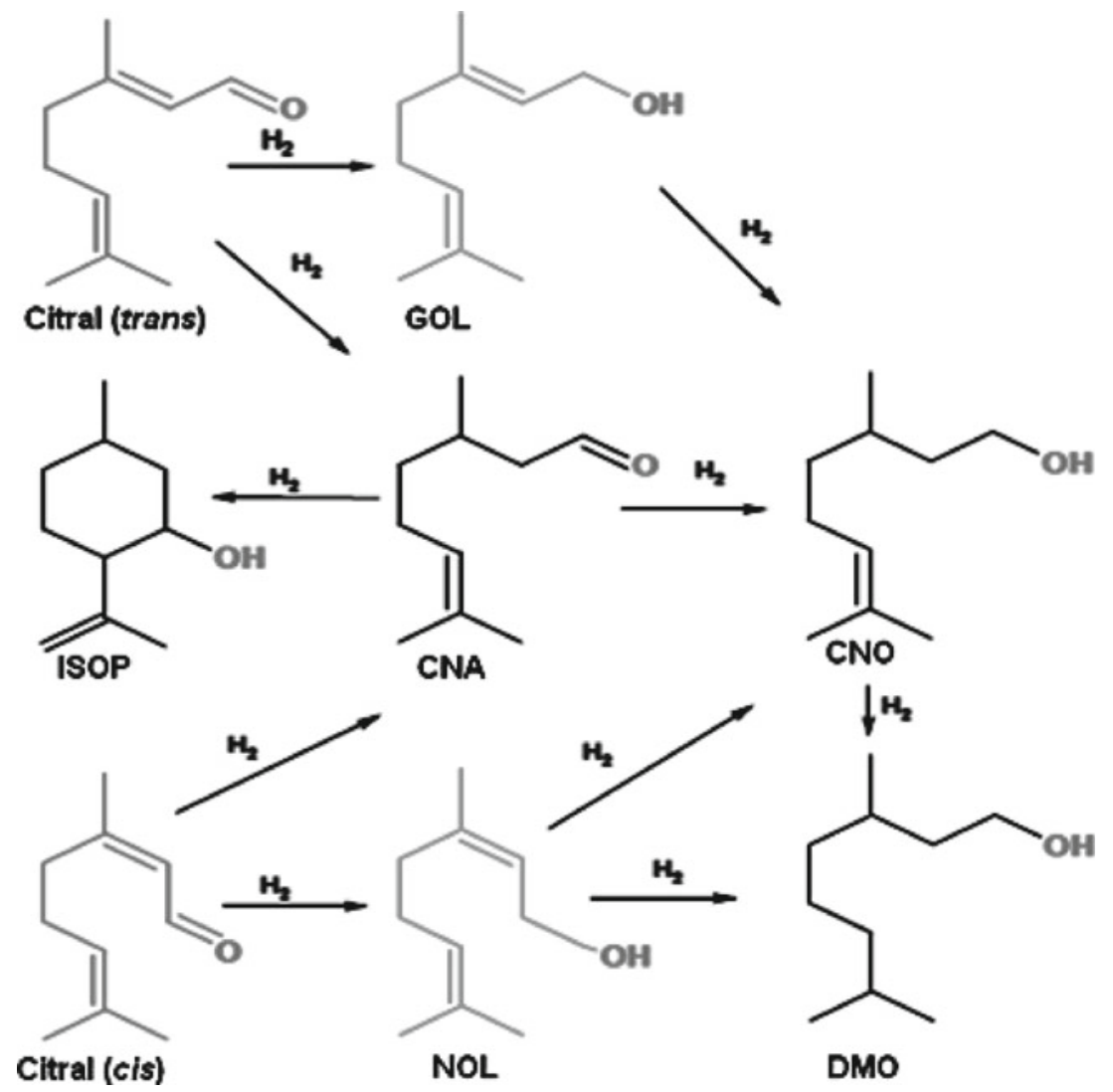

Scheme 1. Reaction pathway of citral hydrogenation.

$375^{\circ} \mathrm{C}$ and $575^{\circ} \mathrm{C}$ and characterized by Fourier transform infrared spectroscopy (FT-IR), Brunauer, Emmett and Teller (BET) surface area, X-ray diffraction (XRD), scanning electron microscopy (SEM) with Energy Dispersive X-ray Analysis (EDAX), transmission electron microscopy (TEM) and X-ray photoelectron spectroscopy (XPS) techniques and their catalytic activity for selective hydrogenation of citral towards unsaturated alcohols (GOL and NOL).

\section{Experimental}

\subsection{Catalyst preparation}

Solutions of metal precursors $\mathrm{H}_{2} \mathrm{PtCl}_{6} \cdot 6 \mathrm{H}_{2} \mathrm{O}(0.1992 \mathrm{~g}$ in $10 \mathrm{~mL}$ water $)$ and $\mathrm{PdCl}_{2}(0.1250 \mathrm{~g}$ in $10 \mathrm{~mL}$ water $)$ were mixed together by stirring. Dispersion of $\mathrm{TiO}_{2}$ $(9.85 \mathrm{~g})$ in $50 \mathrm{~mL}$ water was added to this solution with vigorous stirring and the resulting suspension was aged at $80^{\circ} \mathrm{C}$ for $24 \mathrm{~h}$ with stirring. An aqueous solution of $\mathrm{NaBH}_{4}(0.4116 \mathrm{~g}$ in $10 \mathrm{~mL}$ water) was added dropwise into this suspension with vigorous stirring. The $\mathrm{NaBH}_{4}$ aqueous solution was prepared in an ice bath, and molar ratio of $\mathrm{NaBH}_{4}$ : ( $\mathrm{Pt}$ and $\mathrm{Pd}$ ) was 10 . The prepared nanocatalysts denoted were as $\mathrm{Pt}-\mathrm{Pd} / \mathrm{TiO}_{2} 375$ and
$\mathrm{Pt}-\mathrm{Pd} / \mathrm{TiO}_{2} 575$. The same produce is used for $\mathrm{Pt}-\mathrm{Ru}$ and $\mathrm{Pt}-\mathrm{Au}$ nanocatalysts.

\subsection{BET surface area and X-ray diffraction}

The BET surface area measurements were made on a Micromeritics Gemini 2360 instrument by $\mathrm{N}_{2}$ adsorption at liquid nitrogen temperature. Prior to measurements, samples were oven dried at $393 \mathrm{~K}$ for $12 \mathrm{~h}$ and flushed with argon gas for $2 \mathrm{~h}$. XRD patterns were recorded on a Siemens D-5000 diffractometer, using $\mathrm{Ni}$-filtered $\mathrm{Cu} \mathrm{K}_{\alpha}(0.15418 \mathrm{~nm})$ radiation source range of $20-90^{\circ}$ was employed to determine the phase of the modified $\mathrm{TiO}_{2}$ powders. Crystalline phases were identified with the help of ASTM Powder Data Files.

\subsection{Scanning electron microscopy and transmission electron microscopy}

The SEM analyses were carried out with a Jeol JSM 5410 microscope, operating with an accelerating voltage of $15 \mathrm{kV}$. Micrographs were taken after coating by gold sputtering. Elemental analysis was carried out on a Kevex, Sigma KS3 Energy Dispersive X-ray Analysis (EDAX) instrument operating at a detector resolution of 
$136 \mathrm{eV}$. TEM studies were carried out on a JEOL-JEM 100 electron microscope. Samples for direct examination were prepared by suspending the powder in ethanol, and a drop of the suspension was allowed to dry on a copper grid coated with a carbon film. Extractive replica was performed by ultrasonically dispersing the catalyst powder and depositing a drop of the suspension on freshly cleaved mica. After drying, the dispersed powder was covered with a carbon film. The mica was then plunged into a solution containing a mixture of water, acetone and hydrofluoric acid. The acid concentration was chosen in order to dissolve the support without dissolving the metal particles. They remained stuck to the carbon film, which was collected on a copper grid. Area distribution of particles was determined by counting a large number of particles on the TEM micrographs and by plotting $n_{i} d_{i}^{2}$ as a function of $d_{i}\left(n_{i}\right.$ is the number of particles within different intervals with a given average diameter $d_{i}$ ). Mean surface diameter of the particles is then given by $d=\sum n_{i} d_{i}^{3} / \sum n_{i} d_{i}^{2}$. High-resolution TEM (HRTEM) images were obtained by employing a JEOL-3010 device with $300 \mathrm{kV}$ accelerating voltage.

\subsection{X-ray photoelectron spectroscopy}

XPS was used to analyse the atomic surface concentration on each catalyst. The spectra were recorded on a Perkin-Elmer model 5300 X-ray photoelectron spectrometer using $\mathrm{Mg} \mathrm{K} \alpha-1253.6 \mathrm{eV}$ as a radiation source at $300 \mathrm{~W}$. All binding energies were referenced to the $\mathrm{C} 1 \mathrm{~s}$ peak at $284.6 \mathrm{eV}$, which is invariably present on the film surface. The spectra were fitted by XPSPEAK with a linear background and to $80 \%$ Gaussian $/ 20 \%$ Lorentzian peak shape. The structure of anatase $\mathrm{TiO}_{2}$ provided in the article was constructed by the Ca.R.Ine version 3.1 crystallography program package.

\subsection{Activity test}

Citral (mixture of $\mathrm{E}$ and $\mathrm{Z}$ forms, Merck, 99\%) and isopropanol (Fluka, 99.5\%) were used as received. Liquid phase citral hydrogenation experiments were performed in a stirred semi-batch reactor (model 4574, Parr Instrument Co.). Before the reaction, the catalysts were reduced in situ under hydrogen (gas purity, $99.995 \%$ ) flow ( $80-100 \mathrm{~mL} / \mathrm{min})$ for $2 \mathrm{~h}$ under $10 \mathrm{MPa}$ at $250^{\circ} \mathrm{C}$. Then, the reactor was cooled to reaction temperature. Reactant mixture $(200 \mathrm{~mL}$ of $0.1 \mathrm{M}$ citral in isopropanaol) was injected into the bubbling unit to remove the dissolved oxygen before it entered the reactor and reach the catalysts. Citral hydrogenation reaction was performed at $90^{\circ} \mathrm{C}, 10 \mathrm{MPa}$ and at a stirring speed of $750 \mathrm{rpm}$. Preliminary runs carried out at different stirring rates, loading and catalyst grain size
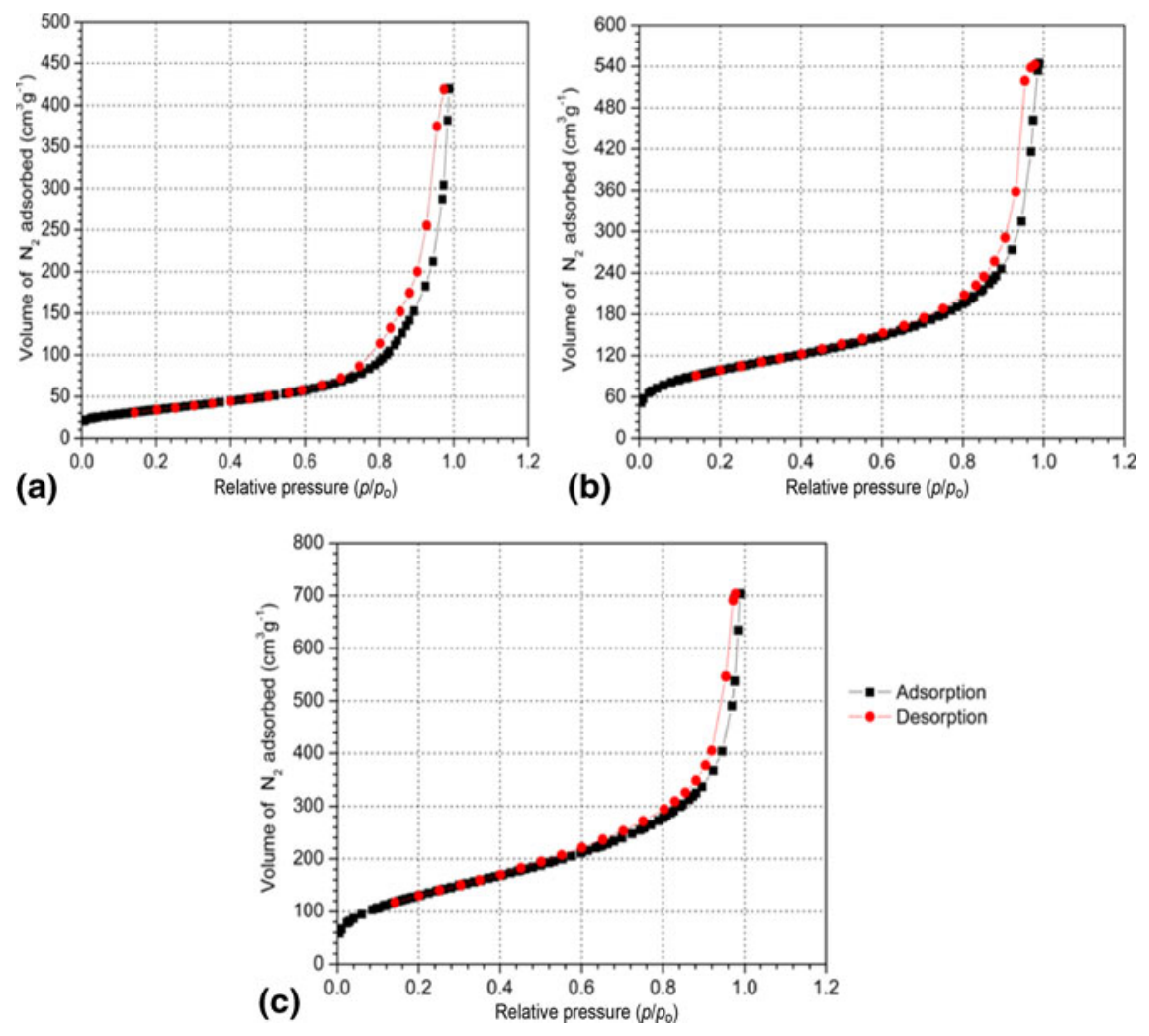

Figure 1. $\mathrm{N}_{2}$ adsorption/desorption isotherm of bimetallic catalyst: (a) $\mathrm{Pt}-\mathrm{Pd} / \mathrm{TiO}_{2}$, (b) $\mathrm{Pt}-\mathrm{Ru} / \mathrm{TiO}_{2}$ and (c) $\mathrm{Pt}-\mathrm{Au} / \mathrm{TiO}{ }_{2}$. 
Table 1. $\mathrm{N}_{2}$ adsorption-desorption measurements for $\mathrm{TiO}_{2}$-supported bimetallic ( $\mathrm{Pt}-$ $\mathrm{Pd}, \mathrm{Pt}-\mathrm{Ru}$ and $\mathrm{Pt}-\mathrm{Au}$ ) nanocatalysts.

\begin{tabular}{|c|c|c|c|c|c|c|c|}
\hline \multirow[b]{2}{*}{ Nanocatalysts } & \multicolumn{4}{|c|}{ Metal loading (mol\%) } & \multirow[b]{2}{*}{$S_{\mathrm{BET}}\left(\mathrm{m}^{2} / \mathrm{g}\right)^{\mathrm{b}}$} & \multirow[b]{2}{*}{$D_{\text {pore }}(\mathrm{nm})^{\mathrm{c}}$} & \multirow[b]{2}{*}{$V_{\text {pore }}\left(\mathrm{cm}^{3} / \mathrm{g}\right)^{c}$} \\
\hline & $\mathrm{Pt}$ & $\mathrm{Pd}$ & $\mathrm{Ru}$ & $\mathrm{Au}$ & & & \\
\hline $\mathrm{Pt}-\mathrm{Pd} / \mathrm{TiO}_{2} 375$ & 0.8 & 0.7 & - & - & 46 & 18.1 & 0.27 \\
\hline $\mathrm{Pt}-\mathrm{Pd} / \mathrm{TiO}_{2} 575$ & 0.9 & 0.6 & - & - & 44 & 20.3 & 0.22 \\
\hline $\mathrm{Pt}-\mathrm{Ru} / \mathrm{TiO}_{2} 375$ & 0.8 & - & 0.7 & - & 49 & 17.4 & 0.21 \\
\hline $\mathrm{Pt}-\mathrm{Ru} / \mathrm{TiO}_{2} 575$ & 0.7 & - & 0.8 & - & 45 & 21.2 & 0.15 \\
\hline $\mathrm{Pt}-\mathrm{Au} / \mathrm{TiO}_{2} 375$ & 0.8 & - & - & 0.7 & 58 & 18.2 & 0.18 \\
\hline $\mathrm{Pt}-\mathrm{Au} / \mathrm{TiO}_{2} 575$ & 0.9 & - & - & 0.7 & 53 & 19.8 & 0.17 \\
\hline
\end{tabular}

${ }^{a}$ ICP method

${ }^{\mathrm{b}}$ Specific surface area deduced from isothermal analysis at liquid nitrogen temperature in relative pressure range from 0.05 to 1.00

${ }^{\mathrm{c}}$ Total pore volume

${ }^{\mathrm{d}}$ Pore diameter calculated using Barret-Joyner-Halenda (BJH) method

demonstrated the absence of internal and external transfer limitations under the selected conditions. Liquid samples were periodically withdrawn through sample tube extending inside the reactor and analysed in a HP 4890 gas chromatography (GC) furnished with an HP 5 semi-capillary column of $15 \mathrm{M}$ and $0.53 \mathrm{~mm}$ ID. The GC analysis was performed using a flame ionization detector, using helium gas as carrier and the column was kept at a constant temperature, i.e., at $393 \mathrm{~K}$. Under these analytical conditions, the product peaks are identified by the use of mass spectroscopy-gas chromatography (GCMS QP2010 Plus). From the results obtained in these analyses, information such as catalytic activity, selectivity of the reaction and conversion could be derived.

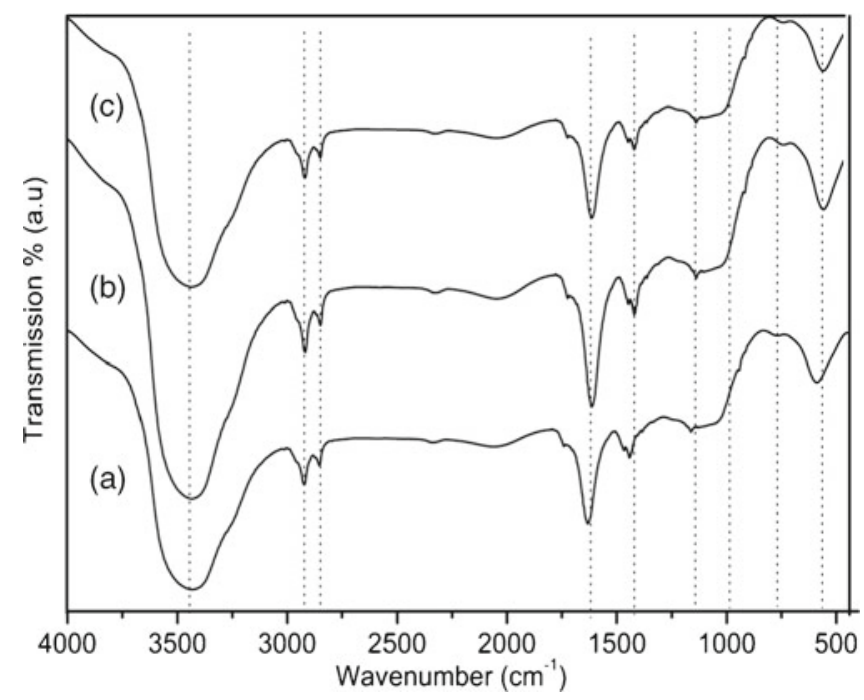

Figure 2. FTIR spectra of (a) $\mathrm{Pt}-\mathrm{Pd} / \mathrm{TiO}_{2}$, (b) $\mathrm{Pt}-\mathrm{Ru} / \mathrm{TiO}_{2}$ and (c) $\mathrm{Pt}-\mathrm{Au} / \mathrm{TiO}_{2}$ bimetallic nanocatalysts reduced at $375^{\circ} \mathrm{C}$.

\section{Results and discussion}

\subsection{Physicochemical characterization}

3.1a Surface area measurement: Figure 1 shows $\mathrm{N}_{2}$ adsorption-desorption isotherm of $\mathrm{Pt}-\mathrm{Pd} / \mathrm{TiO}_{2}, \mathrm{Pt}-$ $\mathrm{Ru} / \mathrm{TiO}_{2}$ and $\mathrm{Pt}-\mathrm{Au} / \mathrm{TiO}_{2}$ nanocatalysts. According to IUPAC nomenclature, all the isotherms are type IV isotherms. ${ }^{31}$ Sharp adsorption and desorption steps followed by a plateau at high $P / P_{\mathrm{o}}$, which is characteristic of capillary condensation and evaporation in the pores, are clearly observed. ${ }^{32}$ A hysteresis loop similar to H1type is observed for the $\mathrm{TiO}_{2}$ support. The hysteresis loop changes with incorporation of noble metals. Then, evolution from $\mathrm{H} 1$ to $\mathrm{H}_{2}$-type is observed (figure 1). Absence of any sharp rise in nitrogen uptake as $P / P_{\mathrm{o}}$ nears 1 also tends to conclude on a homogeneous pore size repartition, without large pores in the support. ${ }^{33,34}$

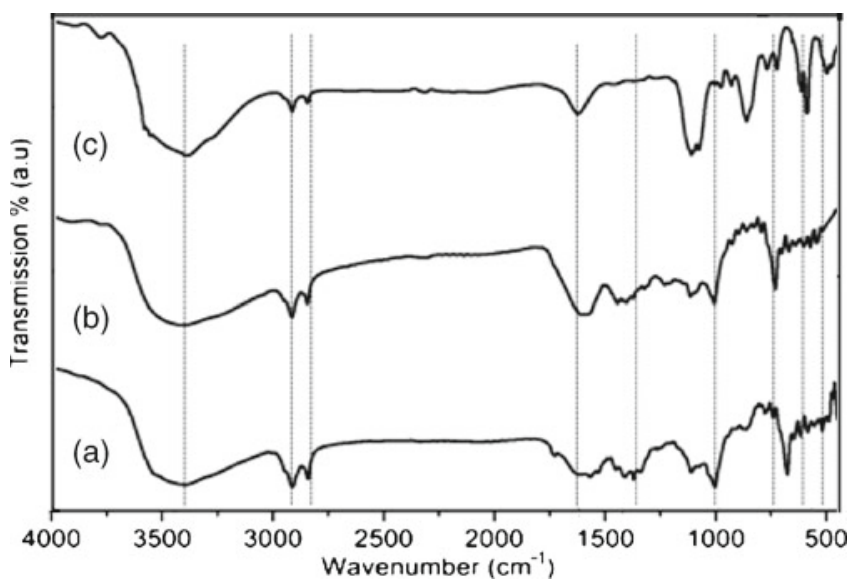

Figure 3. FTIR spectra of (a) $\mathrm{Pt}-\mathrm{Pd} / \mathrm{TiO}_{2}$, (b) $\mathrm{Pt}-\mathrm{Ru} / \mathrm{TiO}_{2}$ and (c) $\mathrm{Pt}-\mathrm{Au} / \mathrm{TiO}_{2}$ bimetallic nanocatalysts reduced at $575^{\circ} \mathrm{C}$. 
Table 2. FT-IR Band assignments of bimetallic ( $\mathrm{Pt}-\mathrm{Pt}, \mathrm{Pt}-\mathrm{Ru}$ and $\mathrm{Pt}-\mathrm{Au}$ ) supported on $\mathrm{TiO}_{2}$ reduced at $375^{\circ} \mathrm{C}$ (a) and $575^{\circ} \mathrm{C}($ b).

\begin{tabular}{lrrrrrr}
\hline & \multicolumn{5}{c}{ Wave number $\left(\mathrm{cm}^{-1}\right)$} \\
\cline { 2 - 7 } Band assignment & 520 & 520 & 523 & 521 & 520 & 523 \\
\hline Internal bending (Ti-O-Ti) & 608 & 608 & 607 & 607 & 608 & 608 \\
External double bonding (Ti-O-Ti) & 750 & 753 & 752 & 754 & 750 & 751 \\
Internal symmetric stretch (Ti-O-Ti) & 753 Pt-Pd (b) $\mathrm{Pt}-\mathrm{Ru}(\mathrm{a}) \mathrm{Pt}-\mathrm{Ru}(\mathrm{b}) \mathrm{Pt}-\mathrm{Au}(\mathrm{a}) \mathrm{Pt}-\mathrm{Au}(\mathrm{b})$ \\
External asymmetric stretch (Ti-O-Ti) & 985 & 985 & 984 & 985 & 984 & 985 \\
OH bending $\left(\delta_{\mathrm{OH}}\right)\left(\mathrm{H}_{2} \mathrm{O}\right)$ & 1633 & 1633 & 1643 & 1643 & 1637 & 1637 \\
$\mathrm{H}-$ bonded $\mathrm{OH}$ stretching $\left(\mathrm{H}_{2} \mathrm{O}\right)$ & 3477 & 3510 & 3476 & 3510 & 3478 & 3511 \\
\hline
\end{tabular}

In addition, pore size $\left(D_{\mathrm{p}}\right)$ and pore volume $\left(V_{\mathrm{p}}\right)$ (table 1) decrease with increase in reduction temperature of the prepared nanocatalysts. Further, the nanocatalyst exhibits decrease in surface area at higher temperature reduction than at lower temperature. The decrease in pore volume is more marked as shown in table 1.

3.1b FTIR spectroscopy: Infrared spectral study of the prepared bimetallic $\mathrm{Pt}-\mathrm{Pd} / \mathrm{TiO}_{2}, \mathrm{Pt}-\mathrm{Ru} / \mathrm{TiO}_{2}$ and $\mathrm{Pt}-\mathrm{Au} / \mathrm{TiO}_{2}$ nanocatalysts reduced at 375 and $575^{\circ} \mathrm{C}$ are given in figures 2 and 3 respectively, and the data are shown in table 2. Absorption band at $480 \mathrm{~cm}^{-1}$ is due to Ti-O-Ti bending vibration. ${ }^{35}$ The band observed at $750 \mathrm{~cm}^{-1}$ is attributed to the Ti-O-Ti symmetric stretching vibration, and the band at $985 \mathrm{~cm}^{-1}$ corresponds to Ti-OH bending vibration. ${ }^{36-38}$ The band at $1114 \mathrm{~cm}^{-1}$ is due to Ti-O stretching vibration. ${ }^{39,40}$ The presence of band at $1633 \mathrm{~cm}^{-1}$ corresponding to $\mathrm{OH}$ shows that a large number of $\mathrm{OH}$ groups $\left(\mathrm{H}_{2} \mathrm{O}\right)$ exists on the surface of $\mathrm{TiO}_{2}$, which plays a key role in bonding metal ions from the impregnating solution. ${ }^{41}$ It is observed that narrow and more intense peaks at 1074, 964 , and $816 \mathrm{~cm}^{-1}$ in $\mathrm{Pt}-\mathrm{Pd} / \mathrm{TiO}_{2}$ are due to stretching vibrations of Ti-O-Ti bond respectively. Similar features were observed for the other two bimetallic
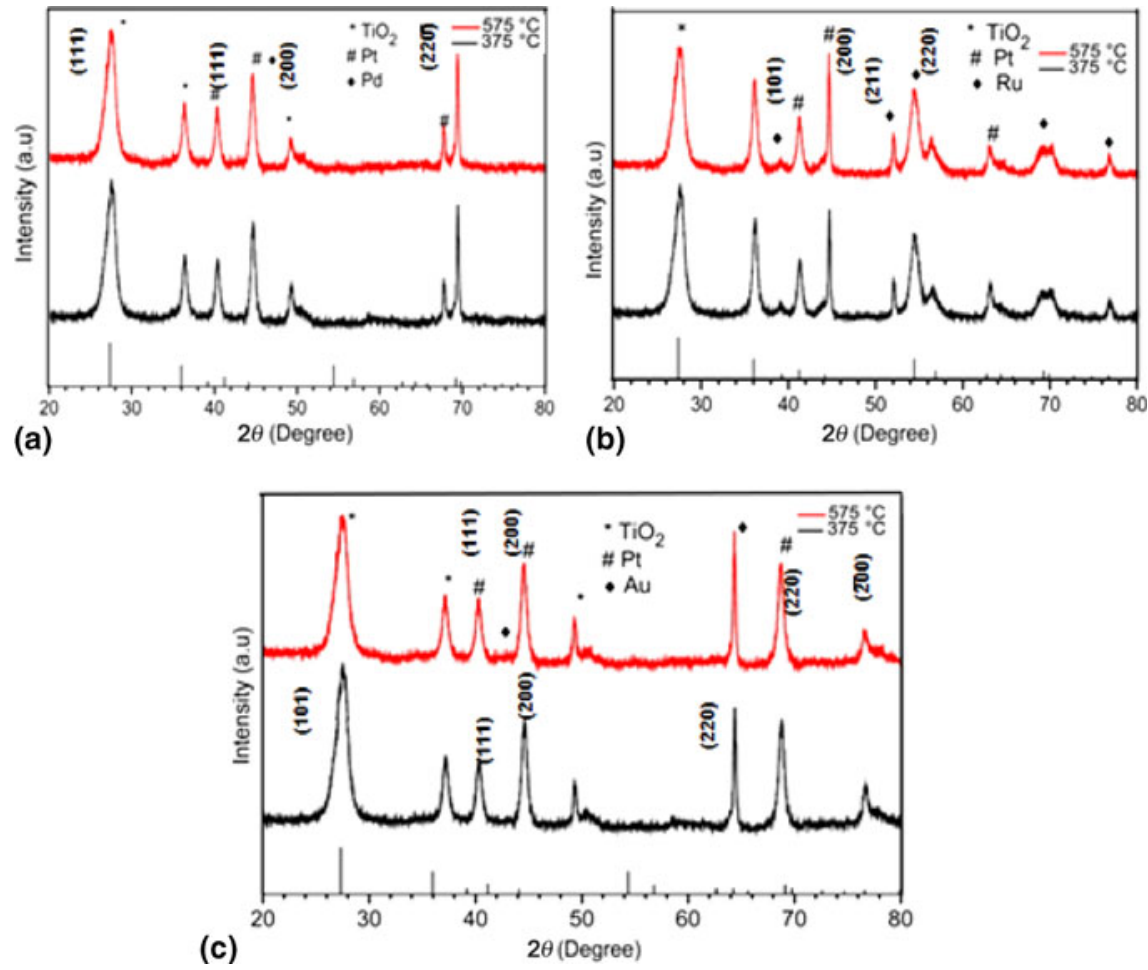

Figure 4. $\mathrm{XRD}$ pattern of (a) $\mathrm{Pt}-\mathrm{Pd} / \mathrm{TiO}_{2}$, (b) $\mathrm{Pt}-\mathrm{Ru} / \mathrm{TiO}_{2}$ and (c) $\mathrm{Pt}-\mathrm{Au} / \mathrm{TiO}_{2}$ nanocatalysts thermally reduced at $375^{\circ} \mathrm{C}$ and $575^{\circ} \mathrm{C}$. 

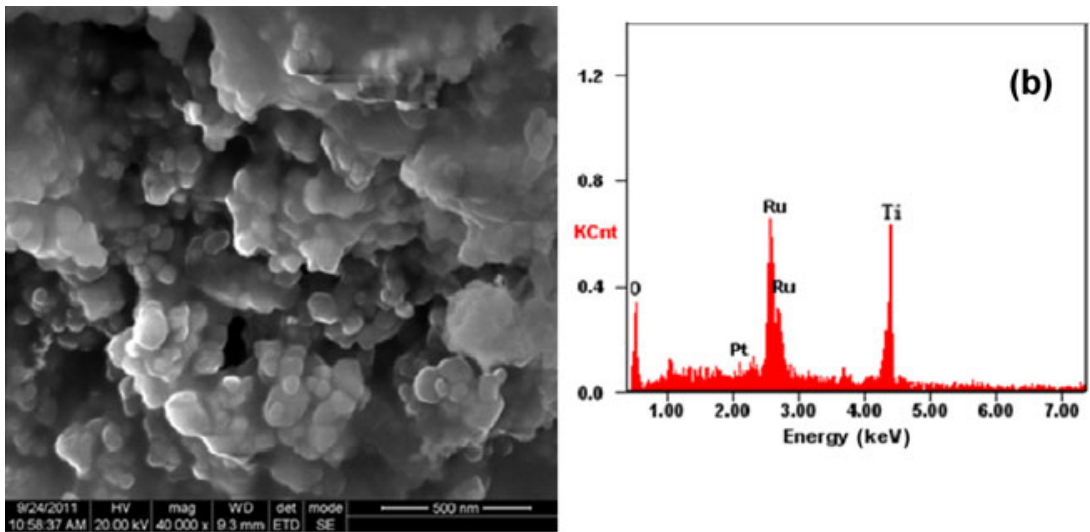

(a)

Figure 5. (a) SEM image of $\mathrm{Pt}-\mathrm{Ru} / \mathrm{TiO}_{2} 575$ and (b) EDAX spectrum of $\mathrm{Pt}-\mathrm{Ru} / \mathrm{TiO}_{2} 575$.
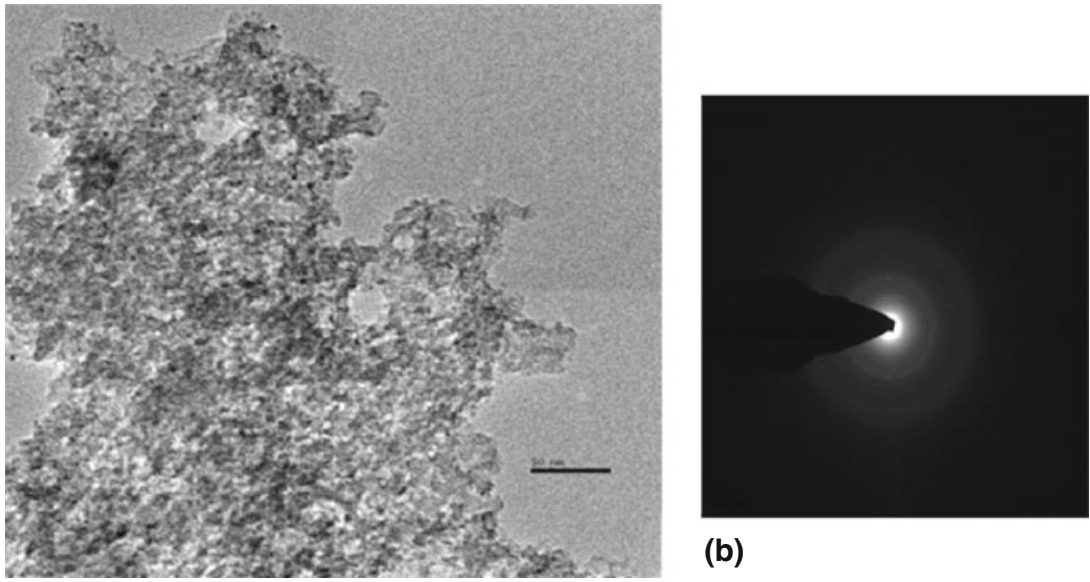

(b)

(a)

Figure 6. HR-TEM images of (a) $\mathrm{Pt}-\mathrm{Ru} / \mathrm{TiO}_{2} 375$ and (b) SAED pattern.
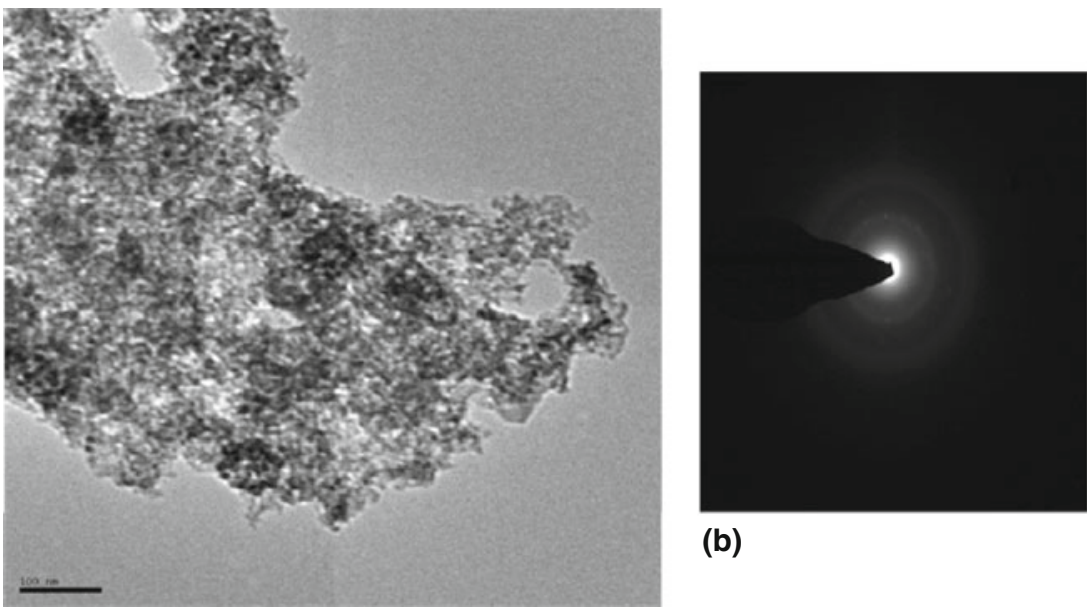

(b)

(a)

Figure 7. TEM images of (a) $\mathrm{Pt}-\mathrm{Ru} / \mathrm{TiO}_{2} 575$ and (b) SAED pattern. 
catalysts. Catalysts reduced at higher temperature show less intense $\mathrm{OH}$ bands compared to catalysts reduced at lower temperature.

3.1c XRD analysis: Powder XRD patterns of Pt$\mathrm{Pd} / \mathrm{TiO}_{2} 375$ and $\mathrm{Pt}-\mathrm{Pd} / \mathrm{TiO}_{2} 575$ nanocatalysts are given in figure $4 \mathrm{a}$, which exhibit diffraction peaks at $25.5^{\circ}$, $37.7^{\circ}$ and $48.2^{\circ}$ that are consistent with corresponding planes of (101), (004) and (200) characteristic of anatase $\mathrm{TiO}_{2}$ (JCPDS 84-1286). ${ }^{42}$ They also exhibit other peaks at $39.9^{\circ}, 46.3^{\circ}$ and $67.45^{\circ}$ with corresponding planes of (111), (200) and (220) characteristic of Pt (JCPDS 04-802); and peaks at $40.1^{\circ}, 46.7^{\circ}$ and $68.1^{\circ}$ with corresponding planes of (111), (200) and (220) of Pd (JCPDS 05-0681) face-centred phase.

Powder XRD patterns of $\mathrm{Pt}-\mathrm{Ru} / \mathrm{TiO}_{2} 375$ and $\mathrm{Pt}-$ $\mathrm{Ru} / \mathrm{TiO}_{2} 575$ nanocatalysts are given in figure $4 \mathrm{~b}$. In figure $4 \mathrm{c}$, the diffraction peaks at $38.3^{\circ}, 42.2^{\circ}, 44.0^{\circ}$, $58.3^{\circ}, 69.5^{\circ}$, and $78.4^{\circ}$ corresponding to (100), (002), (101), (102), (110) planes is due to (JCPDS 06-0663) hexagonal Ru. Furthermore, the diffraction peaks correspond to $\mathrm{Pt}$ and $\mathrm{TiO}_{2}$.

Figure $4 \mathrm{c}$ shows powder XRD patterns of $\mathrm{Pt}-$ $\mathrm{Au} / \mathrm{TiO}_{2} 375$ and $\mathrm{Pt}-\mathrm{Au} / \mathrm{TiO}_{2} 575$ nanocatalysts. Diffraction peaks $38.1^{\circ}, 44.4^{\circ}, 64.3^{\circ}$, and $77.5^{\circ}$ corresponding to (111), (200), (220), (311) and (112) planes are due to fcc phase (JCPDS 06-0663) of Au. Further, diffraction peaks corresponding $\mathrm{Pt}$ and $\mathrm{TiO}_{2}$ are also seen in figure $4 \mathrm{c}$.

3.1d Scanning electron microscopy: Morphology of the synthesized nanocatalysts was investigated using SEM analysis. SEM images and the corresponding EDAX spectra of $\mathrm{Pt}-\mathrm{Ru} / \mathrm{TiO}_{2}$ reduced at $575^{\circ} \mathrm{C}$ is shown in figure 5. Micrographs show that the particles were spherical irregular particles with average diameter in $\mathrm{nm}$ range. For the nanocatalysts, reduced at higher temperature, relatively larger particles are observed due to agglomeration during sintering process. The EDAX spectrum shows the presence of $\mathrm{Pt}$, and $\mathrm{Ru}$ along with $\mathrm{Ti}$ and $\mathrm{O}$.

3.1e Transmission electron microscopy: The prepared nanocatalysts were subjected to TEM analysis to study their morphology. The TEM images and SAED pattern of the $\mathrm{Pt}-\mathrm{Ru} / \mathrm{TiO}_{2}$, nanocatalysts, thermally reduced at $375^{\circ}$ and $575^{\circ} \mathrm{C}$ are given in figures 6 and 7 , respectively. Particles in the samples were spherical and well-dispersed and the size of the particles was in the range of $50-100 \mathrm{~nm}$. It is observed that catalysts reduced at $375^{\circ} \mathrm{C}$ have smaller particle size than

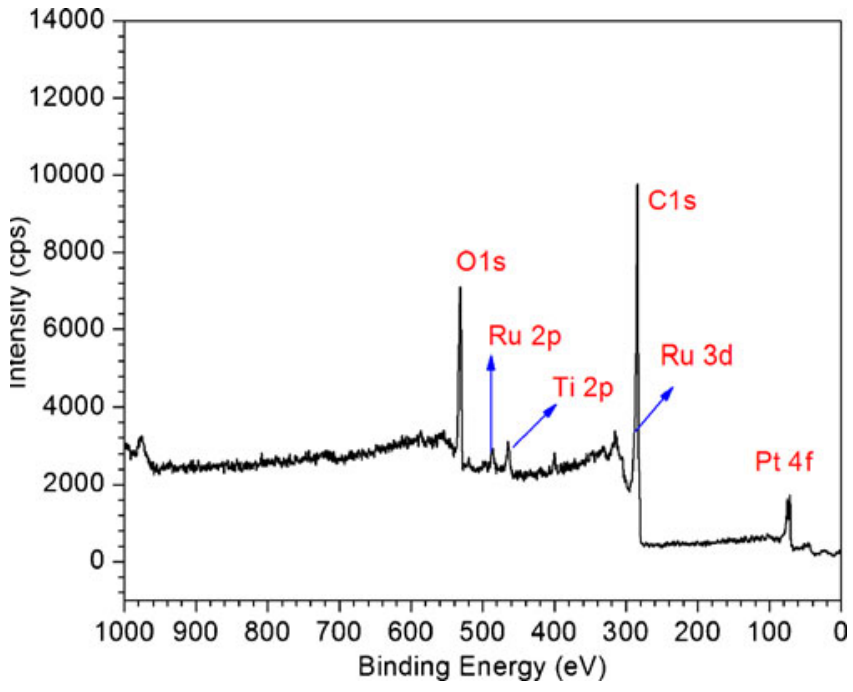

Figure 8. XPS survey spectrum of bimetallic nanocatalysts of $\mathrm{Pt}-\mathrm{Ru} / \mathrm{TiO}_{2}$ reduced at $575^{\circ} \mathrm{C}$.

catalysts reduced at $575^{\circ} \mathrm{C}$. The SAED patterns show that nanocatalysts are crystalline in nature. Reduction at higher temperatures leads to significant increase in size and agglomeration of nanoparticles at the exterior
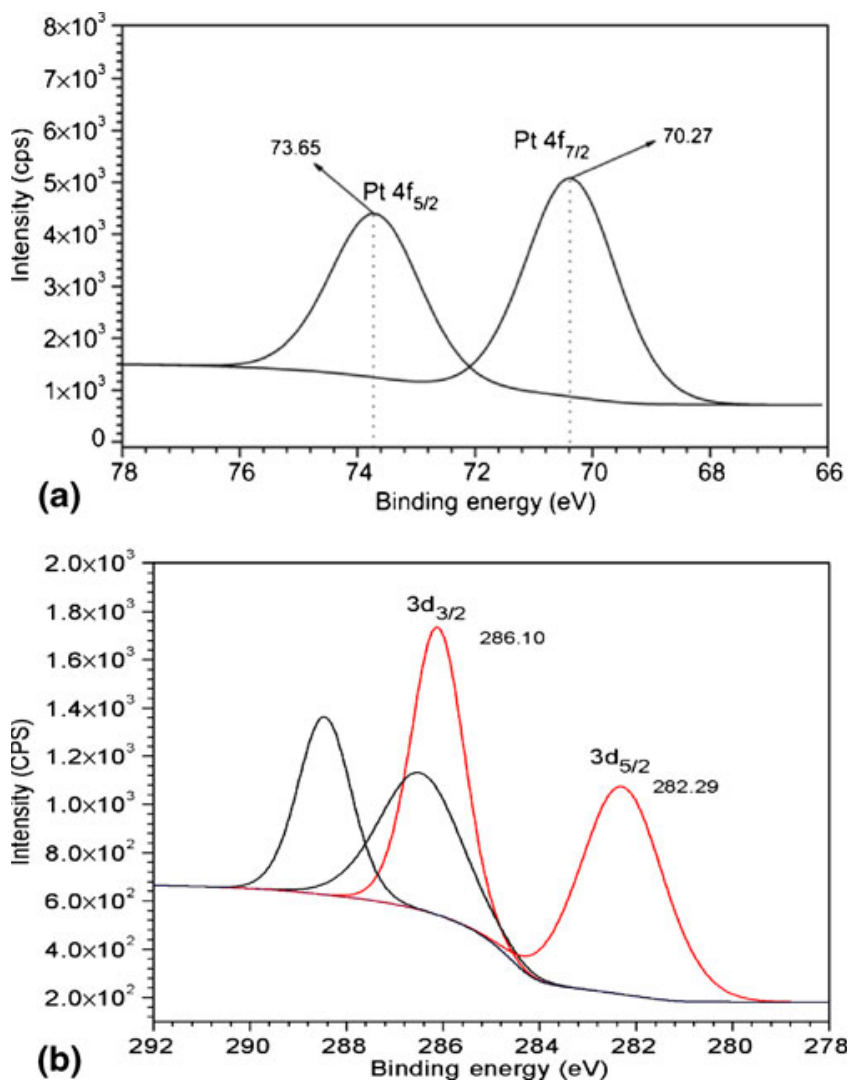

Figure 9. XPS Pt $4 \mathrm{f}(\mathbf{a})$ and $\mathrm{Ru} 3 \mathrm{~d}(\mathbf{b})$ core level spectra of $\mathrm{Pt}-\mathrm{Ru} / \mathrm{TiO}_{2}$ reduced at $575^{\circ} \mathrm{C}$. 

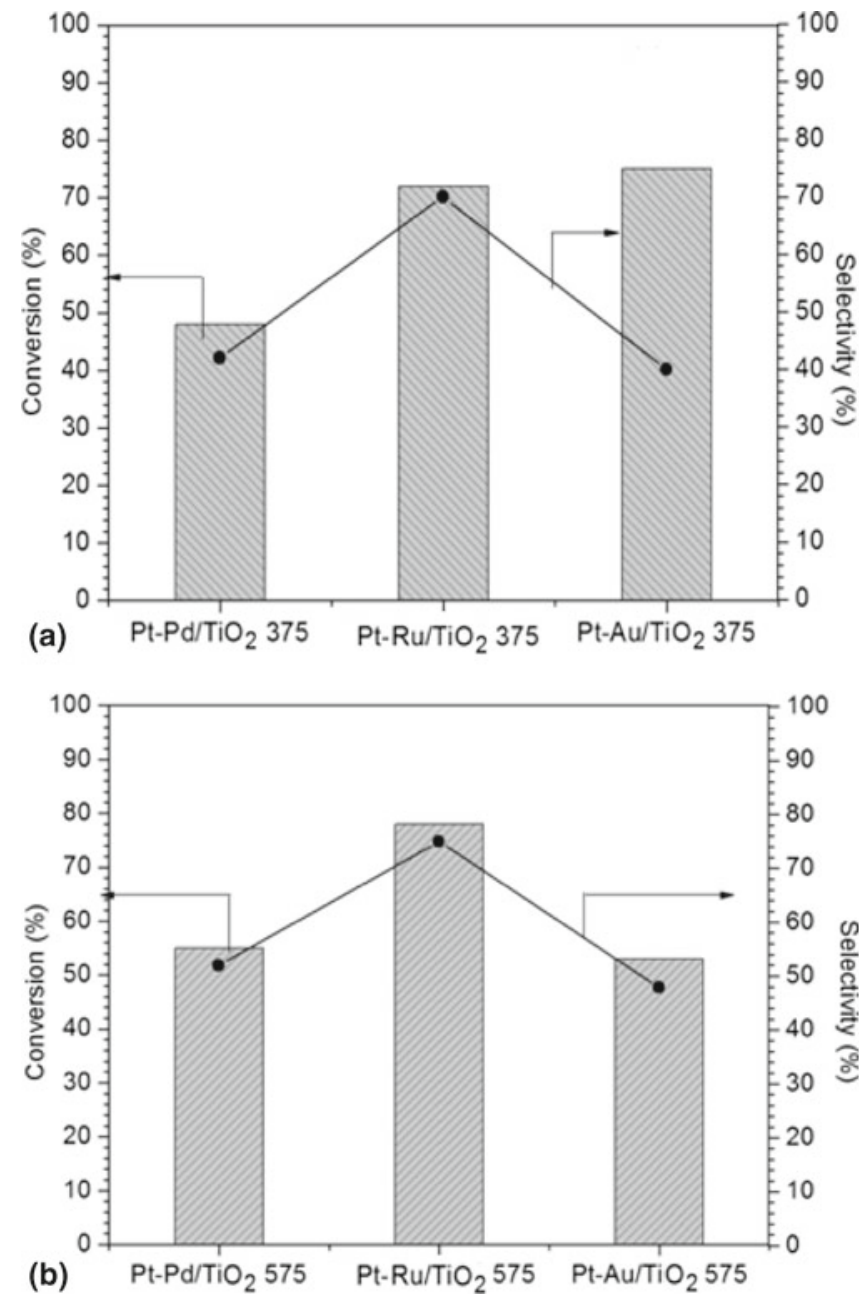

Figure 10. Conversion and selectivity towards unsaturated alcohols as a function of reduction temperature of catalyst (a) $375^{\circ}$ and (b) $575^{\circ} \mathrm{C}$ at $90^{\circ} \mathrm{C}, 10 \mathrm{MPa}, 750 \mathrm{rpm}$, IPA solvent, $1.5 \%$ metal content, and $m=250 \mathrm{Mg}$.

surface compared to the catalysts reduced at lower temperature. High magnification HRTEM images reveal the presence of orderly crystallites in the particles. 3.1f XPS of bimetallic supported on $\mathrm{TiO}_{2}$ nanocatalysts: XPS analysis was conducted to determine oxidation state of the elements. Figure 8 show the survey spectra of $\mathrm{Pt}-\mathrm{Ru} / \mathrm{TiO}_{2} 575$ which exhibit peaks of $\mathrm{Pt}, \mathrm{Ru}$ and along with $\mathrm{Ti}$ and $\mathrm{O}$. Figure 9 shows the core level spectra of $\mathrm{Pt} 4 \mathrm{f}$ and $\mathrm{Ru} 3 \mathrm{~d}$ of $\mathrm{Pt}-\mathrm{Ru} / \mathrm{TiO}_{2} 375$ nanocatalyst. Core level spectrum of $\mathrm{Pt} 4 \mathrm{f}$ shows (figure 9a) two sets of peaks with binding energies of $\mathrm{Pt} 4 \mathrm{f}_{7 / 2}$ at $70.24 \mathrm{eV}$ and $4 \mathrm{f}_{5 / 2}$ at $73.58 \mathrm{eV}$, which suggest that $\mathrm{Pt}$ is present in zerovalent state; and same peaks are observed in higher temperature reduction $\left(\mathrm{Pt} \mathrm{4f_{7/2 }}\right.$ at $70.27 \mathrm{eV}$ and $4 \mathrm{f}_{5 / 2}$ at $73.65 \mathrm{eV}$ ), which suggest the existence of $\mathrm{Pt}^{0}$ species on the surface. Core level spectrum of $\mathrm{Ru} 3 \mathrm{~d}$ spectrum has been obscured (figure $9 \mathrm{~b}$ ) by the $\mathrm{C} 1 \mathrm{~s}(286.6 \mathrm{eV})$ spectrum, but the deconvoluted spectrum shows a doublet with peak binding energies of $282.29 \mathrm{eV}\left(3 \mathrm{~d}_{5 / 2}\right)$ and $286.286 .1 \mathrm{eV}\left(3 \mathrm{~d}_{3 / 2}\right)$. It is difficult to resolve the small $\mathrm{Ru}$ peak from the large peak of $\mathrm{C} 1 \mathrm{~s}$. The Ru3d spectra revealed the presence of only $\mathrm{Ru}^{0}$ at $3 \mathrm{~d}_{5 / 2}$ at $282.32 \mathrm{eV} 48 .{ }^{43-45}$ Regarding the Ti species, curve fitting indicated the presence of the dominant $\mathrm{Ti}^{4+}$ peak.

\subsection{Nanocatalyst testing}

3.2a Effect of second metal addition for higher selectivity of unsaturated alcohols: Figure 10 shows unsaturated alcohol conversion and selectivity as a function of $\mathrm{Pt}-\mathrm{Pd} / \mathrm{TiO}_{2}, \mathrm{Pt}-\mathrm{Ru} / \mathrm{TiO}_{2}$ and $\mathrm{Pt}-\mathrm{Au} / \mathrm{TiO}{ }_{2}$ catalysts, thermally reduced at $375^{\circ} \mathrm{C}$ and $575^{\circ} \mathrm{C}$. Catalysts reduced at low temperature $\left(375^{\circ} \mathrm{C}\right)$ show overall conversion and selectivity of GOL and NOL $48 \%$, $72 \%$ and $45 \%$, and $45 \%, 70 \%$, and $40 \%$ for bimetallic catalysts $\mathrm{Pt}-\mathrm{Pd} / \mathrm{TiO}{ }_{2}, \mathrm{Pt}-\mathrm{Ru} / \mathrm{TiO}_{2}$ and $\mathrm{Pt}-\mathrm{Au} / \mathrm{TiO}{ }_{2}$, respectively (shown in figure 10a). Catalysts thermally reduced at high temperature $\left(575^{\circ} \mathrm{C}\right)$ exhibit overall

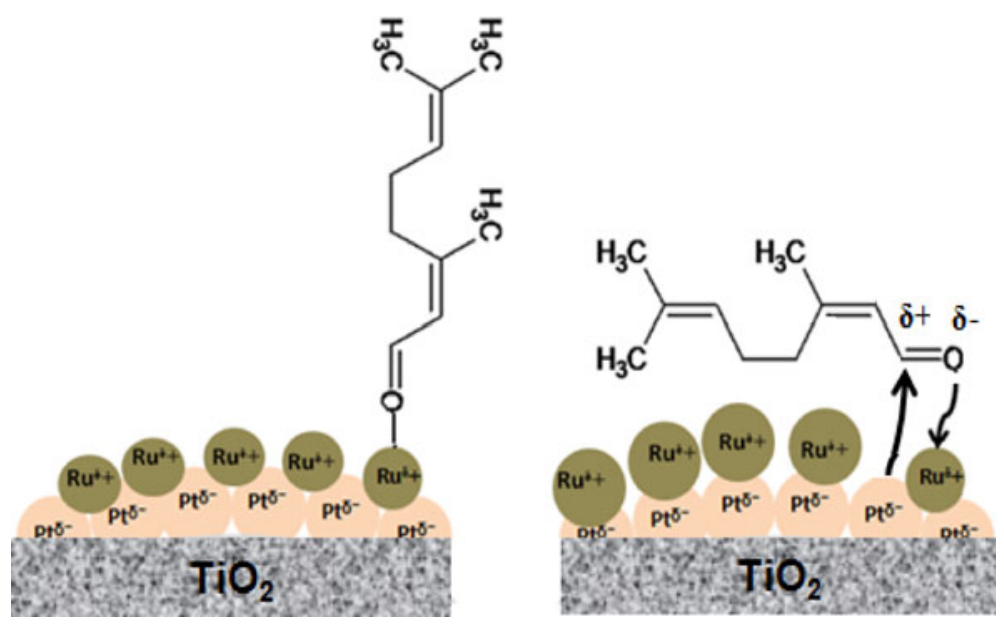

Scheme 2. Adsorption mode of citral. 
conversion and selectivity of GOL and NOL 55\%, 78\% and $53 \%$ and $52 \%, 75 \%$ and $48 \%$ for bimetallic Pt$\mathrm{Pd} / \mathrm{TiO}_{2}, \mathrm{Pt}-\mathrm{Ru} / \mathrm{TiO}{ }_{2}$ and $\mathrm{Pt}-\mathrm{Au} / \mathrm{TiO}_{2}$ catalysts, respectively (shown in figure 10b). Catalysts reduced at $575^{\circ} \mathrm{C}$ show higher activities than their counterparts reduced at $375^{\circ} \mathrm{C}$. Bimetallic catalysts relatively show higher activity than monometallic catalysts, which may be due to the cooperative activity of the two metals. ${ }^{46-51}$

3.2b Effects of ruthenium promoter on Pt catalysts: Among the prepared $\mathrm{TiO}_{2}$-supported bimetallic ( $\mathrm{Pt}-$ $\mathrm{Pd} / \mathrm{TiO}_{2}$ and $\mathrm{Pt}-\mathrm{Ru} / \mathrm{TiO}_{2}$ and $\mathrm{Pt}-\mathrm{Au} / \mathrm{TiO}_{2}$ ) nanocatalysts, $\mathrm{Pt}-\mathrm{Ru} / \mathrm{TiO}_{2}$ shows highest overall conversion and selectivity towards GOL and NOL. The XPS analysis shows presence of $\mathrm{Pt}^{0}$ and $\mathrm{Ru}^{0}$. In the $\mathrm{Pt}-\mathrm{Ru} / \mathrm{TiO}_{2}$ nanocatalyst, the contact between $\mathrm{Pt}$ and $\mathrm{Ru}$ atoms favours partial electronic transfer from $\mathrm{Ru}^{0}$ towards $\mathrm{Pt}^{0}$ due to difference in electronegativity. In this way, there is $+\delta$ charge density in the $\mathrm{Ru}$ atoms and $\mathrm{a}-\delta$ charge density in Pt atoms (scheme 2). Although, Ru, $\mathrm{Pd}$ and Au have the same electronegativity; Ru is a hard acid, whereas $\mathrm{Pd}$ and $\mathrm{Au}$ are soft acids. Considering a molecule of $\alpha, \beta$-unsaturated aldehyde, it is accepted that the $\mathrm{C}=\mathrm{O}$ group could be adsorbed on to the $\mathrm{Ru}$ metal surface ${ }^{49}$ due to partial negative charge $(-\delta)$ on the $\mathrm{O}$ atom, which favours hydrogenation of the $\mathrm{C}=\mathrm{O}$ group resulting in the formation of unsaturated alcohols. Mode of adsorption of citral over Pt-Ru/TiO catalyst is shown in the scheme 2 .

\section{Conclusion}

Characterization techniques showed that $\mathrm{TiO}_{2}$ supported platinum-based bimetallic nanocatalysts have porous nature with high surface area and pore volume. Catalyst reduction at higher temperature leads to an increase in selectivity towards unsaturated alcohols (GOL and NOL) for $\mathrm{Pt}-\mathrm{Ru} / \mathrm{TiO}_{2}$ compared to $\mathrm{Pt}-\mathrm{Pd} / \mathrm{TiO}_{2}$ and $\mathrm{Pt}-\mathrm{Au} / \mathrm{TiO}_{2}$ nanocatalysts. In addition, a second metal $(\mathrm{Ru})$ also leads to an increase in GOL and NOL selectivity during citral hydrogenation. The generated partially oxidized second metal species due to difference in electronegativity, strongly binds the $\mathrm{C}=\mathrm{O}$ group and also paves the way for selective activation of the $\mathrm{C}=\mathrm{O}$ bond.

\section{Acknowledgements}

Authors gratefully acknowledge TEM and XPS facilities provided by National Centre for Nanoscience and Nanotechnology, University of Madras, and thank SAIF IIT Madras.

\section{References}

1. Claus P 1998 Top. Catal. 551

2. Gallezot P and Richard D 1998 Catal. Rev. Sci. Eng. 4081

3. Smith G V and Nothei F 1999 Heterogenous catalysis in organic chemistry (San Diego: Academic Press)

4. Ponec V 1997 Appl. Catal. A 14927

5. Coq B, Figueras F, Geneste P, Moreau C, Moreau P and Warawdekar M 1993 J. Mol. Catal. 78211

6. Reyes P, Rojas H, Pecchi G and Fierro J L G $2002 \mathrm{~J}$. Mol. Catal. A179 293

7. Mukherjee S and Albert Vannice M 2006 J. Catal. 243 108

8. Alvarez-Rodriguez J, Guerrero-Ruiz A, RodriguezRamos I and Arcoya-Martın A 2006 Micropor. Mesopor. Mater. 97122

9. Vilella I M, Borbath I, Margitfalv J L, Lazar K, Miguel de O A and Scelza S R 2007 Appl. Catal. A 32637

10. Neri G, Milone C, Donato A, Mercadante L and Visco A M 1994 J. Chem. Tech. Biotechnol. 6083

11. Serrano-Ruiz J C, Sepulveda-Escribano A, RodriguezReinoso F and Duprez D 2007 J. Mol. Catal. A268 227

12. Chiang S, Yang C, Chen Y and Liaw B 2007 Appl. Catal. A326 180

13. Manikandan D, Divakar D and Sivakumar T 2008 Catal. Lett. 123107

14. Galvagno S, Milone C, Neri G, Donato A and Pietropaolo R 1993 Stud. Surf. Sci. Catal. 78163

15. Centomo P, Zecca M, Lora S, Vitulli G, Caporusso A M, Tropeano M L, Milone C, Galvagno S and Corain B 2005 J. Catal. 229283

16. Neri G, Mercadante L, Donato A, Visco A M and Galvagno S 1994 Catal. Lett. 29379

17. Burgener M, Furrer R, Mallat T and Baiker A 2004 Appl. Catal. A268 1

18. Arvela P M, Tiainen L P, Neyestanaki A K, Sjöholm R, Rantakylä T K, Laine E, Salmi T and Murzin D Y 2002 Appl. Catal. A237 181

19. Consonni M, Jokic D, Murzin D Y and Touroude R 1999 J. Catal. 188165

20. Singh U K and Vannice M A 2001 J. Catal. 19973

21. Malathi R and Viswanath R P 2001 Appl. Catal. A208 323

22. Ammari F, Lamotte J and Touroude R 2004 J. Catal. 22132

23. Abid M, Ehret G and Touroude R 2001 Appl. Catal. A217 219

24. Baeza B B, Rodríguez I and Ruiz A G 2001 Appl. Catal. A205 227

25. Aumo J, Lilja J, Arvela P M, Salmi T, Sundell M, Vainio H and Murzin D Y 2202 Catal. Lett. 84219

26. Silva A M, Santos O A A, Mendes M J, Jordao E and Fraga M A 2003 Appl. Catal. A241 155

27. Li Y, Li Z-G and Zhou R-X 2008 J. Mol. Catal. A279 140

28. Reyes P, Aguirre M C, Fierro J L G, Santori G and Ferretti O 2002 J. Mol. Catal. A184 431

29. Vilella I M J, de Miguel S R and Scelza O A 2008 J. Mol. Catal. A284 161

30. Sordelli L, Psaro R, Vlaic G, Cepparo A, Recchia S, Dossi C, Fusi A and Zanoni R 1999 J. Catal. 182186 
31. Gregg S J and Sing K S 1982 Adsorption surface area and porosity, 2nd ed. (New York: Academic Press)

32. Margolese D, Melero J A, Christiansen S C, Chmelka

B F and Stucky G D 2000 Chem. Mater. 122448

33. Sen T, Tiddy G J T, Casci J L and Anderson M W 2003 Chem. Commun. 92182

34. Zhu H, Jones D J, Zajac J, Dutartre R, Rhomari M and Roziere J 2002 Chem. Mater. 144886

35. Sabataityté J, Oja I, Lenzmann F, Volobujeva O and Krunks M 2006 C.R. Chimie 9708

36. Kim H W, Lee M C, Yoo J C and Hahurst D T 2000 Micropor. Mesopor. Mater. 4176

37. Mihailova B, Valtchev V, Mintova S and Konstantinov L 1996 Zeolites 1622

38. Yu M, Wang Z, Fu J, Wang S, Zhang $\mathrm{H}$ J and Han Y C 2002 Chem. Mater. 142224

39. Yu M, Lin J and Fang J 2005 Chem. Mater. 171783

40. Kook Mah S and Chung I J 1995 Non-Cryst. Solids 183 252

41. Lihitkar N B, Abyaneh M K, Samuel V, Pasricha R, Gosavi S W and Kulkarni S K 2007 J. Coll. Inter. Sci. 314 310
42. Lihitkar N B, Abyaneh M K, Samuel V, Pasricha R, Gosavi S W and Kulkarni S K 2007 J. Coll. Inter. Sci. 314 310

43. Rochefort D, Dabo P and Guay D 2003 Electrochim. Acta $\mathbf{4 8} 4245$

44. Aaltonen T, Alen P and Ritala M 2003 Chem. Vapor Deposit. 945

45. Oh Y J, Moon S H and Chung C H 2001 J. Electrochem. Soc. 148 F56

46. Silva A M, Santos O A A, Mendes M J, Jordão E and Fraga M A 2003 Appl. Catal. A241 155

47. Ismagilov Z R, Matus E V, Yakutova A M, Protasova L N, Ismagilov I Z, Kerzhentsev M A, Rebrov E V and Schouten J C 2009 Catal. Today 147S S81

48. Rojas H, Borda G, Reyes P, Martínez J J, Valencia J, Fierro J L G 2008 Catal. Today 699133

49. Ekou T, Vicente A, Lafaye G, Especel C, Marecot P 2006 Appl. Catal. A314 73

50. Singh U K, Vannice M A 2000 J. Mol. Catal. A163 233

51. Protasova L N, Rebrov E V, Glazneva T S, Berenguer A-Murcia, Ismagilov Z R and Schouten J C 2010 J. Catal. 271161 